\title{
Lupus can be caused by asymptomatic Salmonellosis in Bladder?
}

\author{
José Artur Medina*, Daniel Rabelo, Amanda Gomes, Monique Gonçalves Alves, Roseli Cabett, Sérgio Chammas, Rosa Laiso, Guilherme \\ Rossini, Thalles Anthony Duarte Oliveira, Laerthy Cabral, Mercedes Reyes Hernandes and Durvanei Augusto Maria
}

Biochemical Physiopathology Medicine Faculty of University of São Paulo, Laboratory of Biochemical and Biophysical Butantan Institute, Brazil

We believe that all the symptoms of systemic lupus erythematous (SLE) in the same way that all biochemical, immunological and epidemiological aspects of the disease can be easily justified by analogy, to that is found in urinary tract infections and in Salmonellosis. According our thesis the pathogenic agent of typhoid fever remain hidden in bladder, gallbladder and/or bone marrow of SLE patients, causing a subclinical interstitial cystitis creating the autoantibodies, and consequently, the SLE. For us, if lupic patients were treated with antibiotics until total eradication of Salmonella, usually four weeks, they would be cured. Below, are listed the coincidences and reflections that made us formulate this thesis:

The patients will need adjunctive treatment for Gardnerella, because of its high correlation with urinary infections and for producing nuclear antibodies like Samolnella. The bladder should be treated, in addition to antibiotics, also with vitamin $\mathrm{E}$ and glucan glycamine orally, helping to replace protective mucus. The antibiotic obligatorily need to cover Gardenerella.

Below, are listed the coincidences and reflections that made us formulate this thesis:

Both LES as urinary tract infections share the same interleukins: the IL-8 that is a potent chemotactic factor for neutrophils [1-4] and the IL-18, a stimulator of gamma interferon, secondarily released after kidney injury [5-8]. Proteins released by Salmonella can block the immune activity of neutrophils, in murine models [9].

LES and UTI share the same leukocyte chemotactic factor: $\mathrm{CCl} 2$. $[10,11]$; the same can to cause hydronephrosis $[12,13]$. LES and typhoid fever produce the same macrophage differentiation into his respective tissue lesions: infiltration of CD3+, CD8+ and CD68+ [14,15].

LES and typhoid fever may produce the same alterations in urine during the disease progression: leukocyturia and/or hematuria, and according the kidney function is lost, proteinuria [16,17]. Both in LES as urinary infections, progressively, it is found a decreasing on chondroitin sulfate /heparin sulfate ratio in urine according the disease is developing $[18,19]$.

The blood analysis is also similar in LES and in typhoid fever: neutropenia, anemia and thrombocytopenia may be present in both [20,21]. Lupic patients exhibit increased levels of gamma glutamic transferase levels and coincidently, after an acute typhoid episode, about $3-5 \%$ of individuals become asymptomatic carriers. Many of these infected individuals shows an established infection in their gall bladder [22].

Salmonella is of fecal oral transmission i.e. by contaminated food, water and sexually [23]. The countries that exhibit the greater prevalence of typhoid fever are the same that shows the greater prevalence in LES [24-26].

Salmonella can to induce the formation of autoantibodies [27] against the cell nuclei and therefore, at least theoretically, of to produce all the symptoms of lupus, since it could activate $\mathrm{C} 3$ causing the initial inflammation [28]. The leukocyturia is the most common finding in urine I of LES patients as also in typhoid fever $[21,29]$. S typhi induce the creation of immune complexes formed by IgM with C3 activation and consequently glomerulitis [30,31], as the same way that is descripted in lupic nephrite [32].

Interesting to notify that other parasites and protozoa can to positive rheumatoid factors, parasites that may share the same ecological niche with Salmonella, increasing the risk of parasites contamination [33]. However, why the diagnosis is not made? The reason for the failure on making the diagnostic of Salmonellosis in bladder of lupic patients would be outcome of the scarcity of urinary symptoms [34,35], and the negative results seeing in urine assays, more specifically in uroculture. Only $25 \%$ of patients with typhoid fever excrete $S$ typhi in their urine at some point during their illness [36,37].

The bladder in lupus and in cystitis interstitial are virtually identical $[38,39]$. Cystitis interstitial also is considered an autoimmune disease [40], of not known origin like lupus. Interesting to note, however that the use of antibiotics in cystitis interstitial, doxycycline for the couple, cure $70 \%$ of the cases and alleviate the symptoms in all cases [41]. Both urinary infections as LES affects much more the women than the man, the peak of prevalence occurs between the ages of 15 and 28 linking it with probable sexual activity $[42,43]$. It would justify why patients with Klinefelter syndrome are prone of develop lupus, perhaps by the less self-care that increase the risk of parasitosis contaminations as urinary tract infections [44] and the fever when lupic patients are worsening [45-47]. Therefore, if lupus is secondary to a simple case of cystitis produced by an undiagnosed Salmonella, the treatment of lupus should firstly be based on preventing reinfection, questioning the quality of the food and water that the patient currently drinks and sexual partners. Any water ingested that is not from a selated bottle or fevered is suspect. Not forgetting the several other potential ways of be contaminated like the contact with birds, chickens and reptiles.

${ }^{\star}$ Correspondence to: Medina JA, Doctoral student, University of Brasília, Brazil, E-mail: j.a.medina@terra.com.br

Received: Novemer 24, 2020; Accepted: February 09, 2021; Published: February 12, 2021 
Having made this consideration, perhaps SLE deserve be investigated like potential outcome of a subclinical Salmonellosis.

\section{References}

1. Yan-Mei M, Zhao CN, Liu LN, Wu Q, Dan YL, et al. (2018) Increased circulating interleukin-8 levels in systemic lupus erythematosus patients: a meta-analysis. Biomark Med 12: 1291-1302. [Crossref]

2. Rojas M (2018) Cytokines and inflammatory mediators in systemic lupus erythematosus. Rheumatology.

3. Yue-Chau K (1993) Elevated interleukin-8 levels in the urine of patients with urinary tract infections. Infect immune 61: 1307-1314.

4. Benson M (1996) Interleukin (IL)-6 and IL-8 in children with febrile urinary tract infection and asymptomatic bacteriuria. J Infectious Dis 174: 1080-1084.

5. Favilli F, Anzilotti C, Martinelli L, Quattroni P, Martino SD, et al. (2009) IL-18 activity in systemic lupus erythematosus. Ann N Y Acad Sci 1173: 301. [Crossref]

6. Mende R (2018) Analysis of serum interleukin (IL)-1 $\beta$ and IL-18 in systemic lupus erythematosus. Front immun 9: 1250

7. Parikh C, Jani A, Melnikov VY, Faubel S, Edelstein CL (2004) Urinary interleukin-18 is a marker of human acute tubular necrosis. Am J Kidney Dis 43: 405-414. [Crossref]

8. Rodhe Nils (2009) Cytokines in urine in elderly subjects with acute cystitis and asymptomatic bacteriuria. Scand J Prim Health Care 27: 74-79.

9. Cheminay C, Chakravortty D, Hensel M (2004) Role of neutrophils in murine salmonellosis. Infect immun 72: 468-477. [Crossref]

10. Gschwandtner M, Derler R, Midwood KS (2019) More than just attractive: how CCL2 influences myeloid cell behavior beyond chemotaxis. Front immun 10: 2759. [Crossref]

11. Otto G, Burdick M, Strieter R, Godaly G (2005) Chemokine response to febrile urinary tract infection. Kidney int 68.1: 62-70. [Crossref]

12. Easterbrook B (2017) Antibiotic prophylaxis for prevention of urinary tract infections in prenatal hydronephrosis: An updated systematic review. Can Urol Assoc J 11: 3-11. [Crossref]

13. Hong S (2016) Clinical outcomes of hydronephrosis in patients with systemic lupus erythematosus. Int J rheumatic Dis 19: 1317-1321. [Crossref]

14. Chanh N (2004) A clinical, microbiological, and pathological study of intestinal perforation associated with typhoid fever. Clin Infect Dis 39: 61-67. [Crossref]

15. Thorpe R (2014) Site-specific analysis of inflammatory markers in discoid lupus erythematosus skin. The Scientific World Journal 2014:925805. [Crossref]

16. Gasparin A (2020) Urinary soluble VCAM-1 is a useful biomarker of disease activity and treatment response in lupus nephritis. BMC Rheumatol 4: 1-10. [Crossref]

17. Mak A (2007) Renal damage in systemic lupus erythematosus: a comparative analysis of different age groups. Lupus 16: 28-34.

18. Janssen $D$ (2013) The distribution and function of chondroitin sulfate and other sulfated glycosaminoglycans in the human bladder and their contribution to the protective bladder barrier. J Urol 189: 336-342.

19. Lucon M (2014) Evaluation of the metabolism of glycosaminoglycans in patients with interstitial cystis. Int braz j urol 40: 72-79.

20. Mallouh A (1987) White blood cells and bone marrow in typhoid fever. Pediatric Infect Dis $J$ 6: 527-528. [Crossref]

21. Bashal $\mathrm{F}$ (2013) Hematological disorders in patients with systemic lupus erythematosus. The open Rheumatol J 7: 87. [Crossref]

22. Mathai E (1995) Significance of Salmonella typhi bacteriuria. J Clin Microbiol 33: 1791-1792. [Crossref]

23. Reller M (2003) Sexual transmission of typhoid fever: a multistate outbreak among men who have sex with men. Clin Infect Dis 37: 141-144. [Crossref]

24. Narayan S (2016) Update on STIs: Are enteric infections sexually transmitted in British Columbia? Canada Communicable Dis Report 42: 24. [Crossref]
25. Raza M (2012) Systemic lupus erythematosus: disease manifestations in patients from Central Punjab (Pakistan). Int J Clin Rheumatol 7: 607.

26. Patel M (2006) The prevalence and incidence of biopsy-proven lupus nephritis in the UK: Evidence of an ethnic gradient. Arthritis Rheum 54: 2963-2969. [Crossref]

27. Ktsoyan Z (2019) Potential Involvement of Salmonella Infection in Autoimmunity. Pathogens 8: 96. [Crossref]

28. Terato K (2014) Preventing intense false positive and negative reactions attributed to the principle of ELISA to re-investigate antibody studies in autoimmune diseases. $J$ Immunol Methods 407: 15-25. [Crossref]

29. Buka I (1980) Typhoid glomerulonephritis. Arch Dis Childhood 55: 305-307. [Crossref]

30. Saxena R, Mohan C, Mahajan T (2011) Lupus nephritis: current update. Arthritis Res Ther 13: 240. [Crossref]

31. Kumar R, Malaviya AN, Murthy RG, Venkataraman M, Mohapatra LN (1974) Immunological study of typhoid: immunoglobulin's, C3, antibodies, and leukocyte migration inhibition in patients with typhoid fever and TAB-vaccinated individuals. Infect immun 10: 1219-1225. [Crossref]

32. Rajagopalan P, Kumar R, Malaviya AN (1981) Immunological studies in typhoid fever. I. Immunoglobulins, C3, antibodies, rheumatoid factor and circulating immune complexes in patients with typhoid fever. Clin Experimental Immunol 44: 68. [Crossref]

33. Harboe M (1988) Rheumatoid factors in leprosy and parasitic diseases. Scan J Rheumatol 17: 309-313.

34. Koshi G (1976) Uncommon manifestations of Salmonella infections. Ind J Med Res 64 314-321. [Crossref]

35. Mathai E, John TJ, Rani M, Mathai D, Chacko N, et al. (1995) Significance of Salmonella typhi bacteriuria. J clin microbiol 33: 1791-1792. [Crossref]

36. Gilman R, Terminel M, Levine MM, Mendoza PH, Hornick RB (1975) Relative efficacy of blood, urine, rectal swab, bone-marrow, and rose-spot cultures for recovery of Salmonella typhi in typhoid fever. The Lancet 305: 1211-1213. [Crossref]

37. https://www.medscape.com/answers/231135-10644/what-are-genitourinarycomplications-of-typhoid-fever-enteric-fever

38. Fister George M (1938) Similarity of interstitial cystitis (Hunner ulcer) to lupus erythematosus. J Urol 40: 37-51.

39. Boye E, Morse M, Huttner I, Erlanger BF, Mackinnon KJ, et al. (1979) Immune complex-mediated interstitial cystitis as a major manifestation of systemic lupus erythematosus. Clin immunol immunopathol 13: 67-76. [Crossref]

40. Merwe J (2007) Interstitial cystitis and systemic autoimmune diseases. Nat Clin Pract Urol 4: 484-491. [Crossref]

41. Burkhard F, Blick N, Hochreiter WW, Studer UE (2004) Urinary urgency and frequency, and chronic urethral and/or pelvic pain in females. Can doxycycline help? $J$ urol 172: 232-235. [Crossref]

42. Weckerle C, Niewold TB (2011) The unexplained female predominance of systemic lupus erythematosus: clues from genetic and cytokine studies. Clin Rev Allergy Immunol 40: 42-49.

43. Foxman B, Barlow R, Arcy HD, Gillespie B, Sobel JD (2000) Urinary tract infection self-reported incidence and associated costs. Ann Epidemiol 10: 509-515. [Crossref]

44. https://www.ksa-uk.net/home/information-for-medical-professionals/common-healthissues/

45. Feng G, Chen J, Xie Y, Zhou X (2019) Noninfectious Causes of Fever in 128 Patients with Systemic Lupus Erythematosus. Iranian J public health 48: 62. [Crossref]

46. Homa T, Syed A, Haque U, Adler B, Law G, et al. (2018) Fevers in adult lupus patients. Cureus 10: 2098. [Crossref]

47. Beriain J, García SM, Medina FJN, Perdomo DB, Romero AR, Quesada EG (2012) Q-fever can simulate a lupus flare. Reumatología Clínica (English Edition) 8: 143-144. [Crossref]

Copyright: (C2021 Medina JA. This is an open-access article distributed under the terms of the Creative Commons Attribution License, which permits unrestricted use, distribution, and reproduction in any medium, provided the original author and source are credited. 